\title{
Modeling of secondary organic aerosol yields from laboratory chamber data
}

\author{
M. N. Chan ${ }^{1}$, A. W. H. Chan ${ }^{2}$, P. S. Chhabra ${ }^{2}$, J. D. Surratt ${ }^{2}$, and J. H. Seinfeld ${ }^{1,2}$ \\ ${ }^{1}$ Division of Engineering and Applied Science, California Institute of Technology, Pasadena, CA, USA \\ ${ }^{2}$ Division of Chemistry and Chemical Engineering, California Institute of Technology, Pasadena, CA, USA
}

\begin{abstract}
Laboratory chamber data serve as the basis for constraining models of secondary organic aerosol (SOA) formation. Current models fall into three categories: empirical two-product (Odum), product-specific, and volatility basis set. The product-specific and volatility basis set models are applied here to represent laboratory data on the ozonolysis of $\alpha$-pinene under dry, dark, and low- $\mathrm{NO}_{\mathrm{x}}$ conditions in the presence of ammonium sulfate seed aerosol. Using five major identified products, the model is fit to the chamber data. From the optimal fitting, SOA oxygen-tocarbon $(\mathrm{O} / \mathrm{C})$ and hydrogen-to-carbon $(\mathrm{H} / \mathrm{C})$ ratios are modeled. The discrepancy between measured $\mathrm{H} / \mathrm{C}$ ratios and those based on the oxidation products used in the model fitting suggests the potential importance of particle-phase reactions. Data fitting is also carried out using the volatility basis set, wherein oxidation products are parsed into volatility bins. The product-specific model is most likely hindered by lack of explicit inclusion of particle-phase accretion compounds. While prospects for identification of the majority of SOA products for major volatile organic compounds (VOCs) classes remain promising, for the near future empirical product or volatility basis set models remain the approaches of choice.
\end{abstract}

\section{Introduction}

Laboratory chamber data are needed to determine secondary organic aerosol (SOA) yields from volatile organic compounds (VOCs). The fundamental concept on which all descriptions of SOA formation lies is that SOA comprises a mixture of semivolatile organic compounds that partition be- tween the gas and particle phases (Pankow, 1994a,b; Odum et al., 1996; Hallquist et al., 2009). Gas-particle partitioning of each compound is described by an equilibrium partitioning coefficient, $K_{p}$,

$$
K_{p}=\frac{P}{G M} \sim \frac{1}{c^{*}}
$$

where $G$ is the mass concentration per unit volume of air $\left(\mu \mathrm{g} \mathrm{m}^{-3}\right)$ of the semivolatile species in the gas phase, $P$ is the mass concentration per unit volume of air $\left(\mu \mathrm{g} \mathrm{m}^{-3}\right)$ of the semivolatile species in the particle phase, and $M$ is the mass concentration per unit volume of air $\left(\mu \mathrm{g} \mathrm{m}^{-3}\right)$ of the total absorbing particle phase. The equilibrium partitioning coefficient, $K_{p}\left(\mathrm{~m}^{3} \mu \mathrm{g}^{-1}\right)$, is inversely proportional to the saturation vapor concentration, $c^{*}\left(\mu \mathrm{g} \mathrm{m}^{-3}\right)$, of the pure semivolatile compound (see Appendix A). $M$ refers only to the portion of the particulate matter participating in absorptive partitioning (organic aerosol into which semivolatile organics can partition and the aqueous portion of the particles in the case of water-soluble organics). Note that as long as some absorbing mass is present, some fraction of a given semivolatile compound partitions into the particle phase, even if its gas-phase concentration is below its saturation vapor concentration, $c^{*}$.

Oxidation of a parent VOC leads to a variety of semivolatile products, each with its own saturation vapor concentration. Moreover, the semivolatile oxidation products may be formed from first- or higher generation gas-phase reactions, and the products themselves may react further in the gas phase to yield compounds of either lower (in the case of addition of more functional groups) or greater (in the case in which the carbon backbone of the molecule is cleaved) volatility.

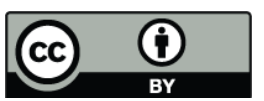

Correspondence to: J. H. Seinfeld

(seinfeld@caltech.edu)

Published by Copernicus Publications on behalf of the European Geosciences Union. 
The fraction $F$ of a semivolatile compound in the particle phase can be expressed in terms of $K_{p}$ or $c^{*}$ as

$F=\frac{P}{G+P}=\frac{M K_{p}}{1+M K_{p}}=\frac{1}{1+c^{*} / M}$

As the amount of absorbing material $(M)$ increases, compounds of greater volatility (larger $c^{*}$, smaller $K_{p}$ ) will partition increasingly into the particle phase. When $c^{*}=M$, half of the semivolatile mass resides in the particle phase. If $M \gg c^{*}$, essentially all of the semivolatile species is in the particle phase.

In the first basic model of SOA formation, Odum et al. (1996) represented the process of SOA formation by $n$ semivolatile products and showed that the SOA yield $Y$, defined as the mass of aerosol formed per mass of hydrocarbon reacted, can be expressed as

$Y=M \sum_{i} \frac{\alpha_{i} K_{p, i}}{1+M K_{p, i}}$

where $\alpha_{i}$ is the mass-based stoichiometric coefficient for product $i$ (mass of $i$ produced per mass of parent VOC reacted). Note that $Y$ can exceed 1.0 as a result of the increase of molecular mass of oxidation products (the designation "aerosol mass fraction" is also used for $Y$ ). Equation (3) is an equilibrium model in that it relates the amount of each product formed to the amount of VOC reacted regardless of number of chemical steps involved. While, in principle, $n$ can be as large as desired, in the application of the Odum model usually $n=2$. The two products are not necessarily associated with actual compounds, and the 4 parameters, $\alpha_{1}$, $\alpha_{2}, K_{p, 1}$, and $K_{p, 2}$, are estimated by optimal fitting of Eq. (3) to the data.

SOA forms when gas-phase oxidation products of a hydrocarbon precursor partition between the gas and particle phases. Products with lower vapor pressures partition preferentially to the particle phase; compounds that are more highly functionalized tend to have lower vapor pressures. The degree of partitioning to the particle phase depends also on the quantity of absorbing organic material in that phase into which the compounds can condense; as the mass of absorbing material increases, compounds of higher vapor pressure that tend not to partition to the particle phase under low mass loadings do so at the higher mass loadings. The result is that SOA at low mass loading tends to be enriched in the least volatile (and most oxygenated) products (Bahreini et al., 2005; Shilling et al., 2008). In typical chamber experiments, a range of initial hydrocarbon precursor concentrations is employed in order to determine SOA yields as a function of the mass concentration of organic particles generated. When chamber experiments are conducted over a range of initial VOC concentrations, such experiments afford a view of the full spectrum of oxidation products, thereby facilitating the formulation of chemical mechanisms.

Laboratory chamber studies are limited in duration to about $12 \mathrm{~h}$ or so, as constrained by particle deposition on the chamber walls, whereas the typical atmospheric lifetime of a particle is considerably longer. Chamber studies capture the initial multi-hour VOC oxidation but not that which takes place on a multi-day time scale. The sequence of reactions and associated SOA formation that occur over the duration of a chamber experiment can be termed as the chamber phase. (Stanier et al. (2008) have referred to this as the "prompt" phase.) The chamber or prompt phase chemistry begins with oxidant $\left(\mathrm{OH}, \mathrm{O}_{3}, \mathrm{NO}_{3}\right)$ attack on the $\mathrm{VOC}$, initiating a series of reactions, which can depend critically on $\mathrm{NO}_{\mathrm{x}}$ level, leading to semivolatile products. Experimentally-derived SOA yields reflect the extent of SOA formation over the chamber phase. Reactions that occur on a time scale longer than a chamber experiment can be termed the aging phase, during which the following processes may occur: (1) particle-phase accretion reactions that convert semivolatile condensed products to essentially non-volatile compounds; (2) gas-phase oxidation reactions of chamber phase semivolatile products that are too slow to be important during the chamber phase but are capable of producing compounds of even lower volatility over the aging phase; and (3) gas-particle reactions that convert some particulate material to volatile products. Over the typical time scale and spatial grid scale of atmospheric models, SOA formation occurring on the chamber phase time scale can be considered as taking place essentially instantaneously, suggesting that an equilibrium partitioning model for this phase is appropriate. Over the longer aging time scale, the equilibrium partitioning can be considered to be slowly perturbed as chemical aging takes place.

\section{Form of SOA model}

If a number of products accounting for a significant fraction of the total mass of SOA have been identified, these major products can serve as SOA surrogates in a product-specific model (Pankow et al., 2001; Seinfeld et al., 2001). Upon estimating the vapor pressures, the values of $K_{p}$ of the major products can be determined. For the product-specific model, major identified particle-phase products are chosen as SOA surrogates to represent other chemically similar compounds, and to give a reasonable approximation of gas/particle partitioning of all other products (Pankow et al., 2001). The simulated SOA composition may allow a first approximation of the properties of SOA (e.g., water uptake and cloud condensation nuclei activity). The SOA composition changes with organic mass loading, and the amount of hydrocarbon precursors reacted can be tracked. Using the simulated SOA composition, one can also calculate the aerosol oxygen-to-carbon $(\mathrm{O} / \mathrm{C})$ and hydrogen-to-carbon $(\mathrm{H} / \mathrm{C})$ ratios at different loadings. Simulated ratios for $\mathrm{O} / \mathrm{C}$ and $\mathrm{H} / \mathrm{C}$ can be compared with those measured.

An alternative approach is the volatility basis set, in which the range of products is specified in terms of volatility bins (Donahue et al., 2006; Stanier et al., 2008). The product 
volatilities can be segmented into order-of-magnitude volatility bins (expressed as values of $c^{*}$ ). Since SOA products are grouped into volatility bins, specific information about the chemical composition of SOA is not required. For the volatility basis set, Stanier et al. (2008) present a methodology for selecting the maximum and minimum values of $c^{*}$, and logarithmic spacing between $c^{*}$ values then determines the number of volatility bins.

Either treatment has the potential to reproduce the measured concentrations of major reaction products (both gasphase and particle-phase), even in the absence of details of major particle-phase reactions. On the other hand, if an equilibrium state is not attained during the chamber phase, the kinetics of gas-phase and particle-phase reactions determine the SOA composition. In such cases, development of kinetic models in which reaction products undergo reactions in both gas-phase and particle-phase is needed to describe the SOA formation (Chan et al., 2007).

The goal of this work is to evaluate the product-specific approach to SOA modeling, using a system that has been relatively well characterized in the laboratory: ozonolysis of $\alpha$ pinene. Because of a general lack of complete product identification for any SOA system, as well as uncertainty about the properties of the products, in practical terms, parameters in the model need to be determined by optimal fitting of the model to chamber data.

\section{Ozonolysis of $\alpha$-pinene}

\subsection{Product-specific model}

Ozonolysis of $\alpha$-pinene is, in many respects, an excellent test case for an SOA model. A number of experimental studies exist in the literature, and relatively complete product identification has been carried out. Oxocarboxylic acids, hydroxy oxocarboxylic acids, dicarboxylic acids, oxoaldehydes, and organic peroxides are the major classes of SOA products identified (Yu et al., 1999; Docherty et al., 2005). For the purposes of evaluating the product-specific model it is assumed that there are five major products: pinonic acid, pinic acid, pinonaldehyde, a hydroperoxide, and terpenylic acid (Table 1). These compounds are chosen to reflect the current understanding of the gas-phase products formed in the ozonolysis of $\alpha$-pinene.

The vapor pressure of a product $i$ is estimated by using a group contribution method developed by Pankow and Asher (2008). At a given temperature, the $K_{p, i}$ of the product $i$ is determined by assuming that its activity coefficient, $\zeta_{i}$, is unity, and the molecular weight of product $i$ is taken as the mean molecular weight of the surrogate mixture, $\overline{M W}$, as a first approximation. These assumptions may be reasonable as the range of molecular weights of products is small (168$200 \mathrm{~g} \mathrm{~mol}^{-1}$, see Table 1) and the amount of water present in the particle phase is not significant under dry conditions
$(<5 \%-40 \%$ RH). Bilde and Pandis (2001) measured the vapor pressure of semivolatile products formed from oxidation of biogenic monoterpenes using a laminar flow reactor with uncertainty of $\pm 50 \%$. They reported a vapor pressure of $1.989 \times 10^{-10} \mathrm{~atm}$ for pinic acid at $293 \mathrm{~K}$, which is comparable to the estimated value $\left(4.605 \times 10^{-10} \mathrm{~atm}\right)$ using the Pankow and Asher (2008) model. At a given temperature, the estimated vapor pressures of the major products using the Pankow and Asher (2008) model are lower than that estimated by Jenkin (2004). Hence, the present estimated $K_{p}$ values of major products are larger than those reported by Jenkin (2004). For example, Jenkin (2004) estimated a higher vapor pressure of pinic acid of $4.7 \times 10^{-4}$ torr (or $\left.6.18 \times 10^{-7} \mathrm{~atm}\right)$ at $298 \mathrm{~K}$ compared to that reported by Bilde and Pandis (2001) $\left(4.213 \times 10^{-10} \mathrm{~atm}\right)$.

When the vapor pressure estimation is carried out for the $\alpha$-pinene/ozone system, two sets of two products each are estimated to have very similar $K_{p}$ values. For example, at $293 \mathrm{~K}$, the estimated value of $K_{p}$ of hydroxy pinonic acid $\left(K_{p}=0.2802\right)$ is very close to that of pinic acid $\left(K_{p}=0.2822\right)$, and the estimated $K_{p}$ of pinonic acid $\left(K_{p}=0.0018\right)$ is close to that of hydroxy pinonaldehyde $\left(K_{p}=0.0017\right)$. In such a case, two products of essentially identical vapor pressures cannot be distinguished, and a single product is chosen to represent the two products. Pinonic acid is chosen to represent the pinonic acid, norpinonic acid, hydroxy pinonaldehyde, and isomers. Pinic acid is chosen to represent pinic acid, norpinic acid, hydroxy pinonic acid, and isomers.

The basic chamber data are considered to be in the form of particle mass concentration as a function of VOC reacted. The actual chamber data are in the form of aerosol volume concentration. Aerosol density needed to convert volume to mass concentration is estimated by comparing the aerosol number distribution measured by a differential mobility analyzer with that obtained from the Aerodyne Aerosol Mass Spectrometer (AMS), through the theoretical relationship between mobility diameter and vacuum aerodynamic diameter. $\mathrm{Ng}$ et al. (2006) have shown that for the oxidation of a number of hydrocarbons with a single double bond, the growth curve for one experiment over the course of the experiment ("time-dependent growth curve") follows that of final SOA growth over different experiments. This suggests that in this case the time-dependent SOA growth data can also be used for model data fitting.

Data from ozonolysis of $\alpha$-pinene are obtained from experiments conducted under dry, dark, and low- $\mathrm{NO}_{\mathrm{x}}$ conditions in the presence of dry $\left(\mathrm{NH}_{4}\right)_{2} \mathrm{SO}_{4}$ particles $(\mathrm{Ng}$ et al., 2006; Pathak et al., 2007; Shilling et al., 2008). The SOA yield data cover a range of organic mass loading $(0.5-$ $411 \mu \mathrm{g} \mathrm{m}^{-3}$ ) and are used for the parameterization to model the SOA yield relevant to atmospheric conditions (Presto and Donahue, 2006). An effective SOA density of $1.25 \mathrm{~g} \mathrm{~cm}^{-3}$ is applied for conversion of volume to mass concentration in determination of SOA yield. It is noted that Shilling 
Table 1. Major products chosen to represent the ozonolysis of $\alpha$-pinene under dry, dark, and low- $\mathrm{NO}_{\mathrm{x}}$ conditions in the presence of dry ammonium sulfate particles. ${ }^{a}$ Vapor pressure is determined at $293 \mathrm{~K}$ using a model developed by Pankow and Asher (2008). $K_{p}$ is determined at $293 \mathrm{~K}$ with the assumption of activity coefficient of the products equal to one and the molecular weight of product $i$ is used as mean molecular weight in organic absorbing phase, as a first approximation. ${ }^{\mathrm{b}}$ (Claeys et al., 2009) ${ }^{\mathrm{c}}$ The enthalpy of vaporization, $\Delta H_{v}$ $\left(\mathrm{kJ} \mathrm{mol}^{-1}\right)$ of the product is estimated by plotting the estimated vapor pressure of the product against temperature. The $\Delta H_{v}$ of the product can be estimated from the slope of the line following the Clausius-Clapeyron equation.

\begin{tabular}{|c|c|c|c|c|c|c|c|c|c|c|c|}
\hline & & & & & \multicolumn{4}{|c|}{ Product-Specific Model } & \multicolumn{3}{|c|}{ Volatility Basis Set } \\
\hline & & & & & \multicolumn{2}{|c|}{$\left(K_{p} \times 1\right.$ case $)$} & \multicolumn{2}{|c|}{$\left(K_{p} \times 100\right.$ case $)$} & & & \\
\hline Product & $\begin{array}{l}\text { Chemical } \\
\text { structure }\end{array}$ & $\mathrm{O} / \mathrm{C}$ & $\mathrm{H} / \mathrm{C}$ & $\Delta H_{v}{ }^{c}$ & $K_{p}{ }^{a}\left(c^{*}\right)$ & $\alpha$ & $K_{p}\left(c^{*}\right)$ & $\alpha$ & $K_{p}\left(c^{*}\right)$ & $\alpha$ & $\begin{array}{l}\alpha \text { from Product-Specific } \\
\text { Model }\left(K_{p} \times 100 \text { case }\right)\end{array}$ \\
\hline $\begin{array}{c}\text { Pinic acid } \\
\mathrm{C}_{9} \mathrm{H}_{14} \mathrm{O}_{4} \\
(\mathrm{MW}: 186)\end{array}$ & & 0.444 & 1.556 & 99.89 & $\begin{array}{l}0.2822 \\
(3.544)\end{array}$ & 0.2308 & $\begin{array}{c}28.22 \\
(0.0354)\end{array}$ & 0.0563 & $100(0.01)$ & 0.0707 & $\begin{array}{c}0.0563 \\
\text { (Pinic acid: } c^{*}=0.0354 \text { ) }\end{array}$ \\
\hline $\begin{array}{c}\text { Terpenylic acid b } \\
\mathrm{C}_{8} \mathrm{H}_{12} \mathrm{O}_{4} \\
(\mathrm{MW}: 172)\end{array}$ & & 0.5 & 1.5 & 76.73 & $\begin{array}{l}0.0332 \\
(30.12)\end{array}$ & 0.0172 & $\begin{array}{c}3.32 \\
(0.3012)\end{array}$ & 0.0132 & $10(0.1)$ & 0.0110 & $\begin{array}{c}0.0131 \\
\text { (Terpenylic acid: } c^{*}=0.3012 \text { ) }\end{array}$ \\
\hline $\begin{array}{c}\text { Hydroperoxide } \\
\mathrm{C}_{10} \mathrm{H}_{16} \mathrm{O}_{4} \\
(\mathrm{MW}: 200)\end{array}$ & & 0.4 & 1.6 & 83.99 & $\begin{array}{l}0.0029 \\
(344.8)\end{array}$ & 0.0181 & $\begin{array}{c}0.29 \\
(3.448)\end{array}$ & 0.0173 & $1(1)$ & 0.0120 & $\begin{array}{c}0.0172 \\
\text { (Hydroperoxide: } c^{*}=3.448 \text { ) }\end{array}$ \\
\hline \multirow[t]{2}{*}{$\begin{array}{c}\text { Pinonic acid } \\
\mathrm{C}_{10} \mathrm{H}_{16} \mathrm{O}_{3} \\
(\mathrm{MW}: 184)\end{array}$} & & 0.3 & 1.6 & 81.72 & $\begin{array}{l}0.0018 \\
(555.6)\end{array}$ & 0.6883 & $\begin{array}{c}0.18 \\
(5.556)\end{array}$ & 0.1573 & $0.1(10)$ & 0.1603 & $\begin{array}{c}0.1573 \\
\text { (Pinonic acid: } c^{*}=5.556 \text { ) }\end{array}$ \\
\hline & & & & & & & & & $0.01(100)$ & 0.0210 & - \\
\hline $\begin{array}{c}\text { Pinonaldehyde } \\
\mathrm{C}_{10} \mathrm{H}_{16} \mathrm{O}_{2} \\
(\mathrm{MW}: 168)\end{array}$ & & 0.2 & 1.6 & 69.53 & $\begin{array}{l}1.145 \times 10^{-5} \\
(87334)\end{array}$ & 1 & $\begin{array}{c}1.145 \times 10^{-3} \\
(873.34)\end{array}$ & 0.9380 & $0.001(1000)$ & 0.9554 & $\begin{array}{c}0.9380 \\
\text { (Pinonaldehyde: } c^{*}=873.34 \text { ) }\end{array}$ \\
\hline
\end{tabular}

et al. (2009) reported a higher effective SOA density (1.73$\left.1.4 \mathrm{~g} \mathrm{~cm}^{-3}\right)$ at low organic mass loading $\left(0.5-7 \mu \mathrm{g} \mathrm{m}^{-3}\right)$. The SOA yield data from Shilling et al. (2008) are adjusted to $293 \mathrm{~K}$, using a temperature correction factor suggested by Pathak et al. (2007). Generally, the time-dependent SOA yield data reported by $\mathrm{Ng}$ et al. (2006) are in good agreement with the final SOA yield data reported by Pathak et al. (2007) and Shilling et al. (2008) but are lower than those reported by Shilling et al. (2008) for organic mass loadings less than $2 \mu \mathrm{g} \mathrm{m}^{-3}$. Measurement uncertainties may explain part of the variability in SOA yield data reported by $\mathrm{Ng}$ et al. (2006) at low organic mass loading.

Data, plotted as SOA yield, $Y$, versus organic mass loading, $M$, are shown in Fig. 1 . The SOA yield increases rapidly at low organic mass loading and more slowly at high organic mass loading. Shown in Fig. 1 are the optimal fits to the product-specific and volatility basis set models. In order to evaluate the effect of uncertainty in $K_{p}$ values, results are shown for the estimated values of $K_{p}$ (termed $K_{p} \times 1$ case) and the estimated values of $K_{p}$ increased by a factor of 100 (termed $K_{p} \times 100$ case). Previous modeling studies on this system have also shown that an overall increase of $K_{p}$ of all products of a factor on the order of $10^{2}$ is needed to explain the partitioning (Jenkin, 2004; Chen and Griffin, 2005). In each case, the $\alpha_{i}$ values are determined by optimal fitting to the data. Different sets of $\alpha_{i}$ values produce essentially the same goodness of fit to the overall mass yield. The sets can be discriminated according to how well they fit the SOA composition as compared to that measured. The $\alpha_{i}$ values are chosen to give the best fit to experimental SOA yields and SOA composition. As shown in Fig. 1, the predicted SOA yields agree well with the experimental SOA yield data in both $K_{p} \times 1$ and $K_{p} \times 100$ cases. The $K_{p} \times 100$ case gives a better estimation of SOA yields at low organic mass loading than the $K_{p} \times 1$ case. However, the optimized curves underpredict the SOA yield data reported by Shilling et al. (2008) when the organic mass loading is less than $\sim 2 \mu \mathrm{g} \mathrm{m}^{-3}$.

For the $K_{p} \times 1$ case, the predicted SOA yields are lower than the measured ones at low organic mass loading. The data fitting produces the unrealistic result that the mass yield of the pinonaldehyde is unity. The sum of fitted molar yields exceeds 1 . One likely explanation is the uncertainty in the estimation of the $K_{p}$ of major products (vapor pressure and activity coefficient). The estimated vapor pressure of the products using the group contribution method is too high, and the products are estimated to be too volatile. In order to match experimental SOA yields, large mass yields of the products are predicted so that a significant amount of the products is partitioned into the particle phase. This results in unrealistically high mass yields of the products. Another likely explanation is that other products (gas-phase and/or particle-phase) of higher $K_{p}$ (and lower volatilities) are present. Particle-phase reaction products (e.g., oligomers and esters), which are likely present, tend to have higher molecular weights and lower volatilities (Gao et al., 2004; Iinuma et al., 2004; Müller et al., 2008), effectively enhancing the $K_{p}$ values (Kroll and Seinfeld, 2005). For example, an ester, which is formed between pinic acid and hydroxy pinonic acid, has been detected (Müller et al., 2008). At $293 \mathrm{~K}$, the estimated $K_{p}$ of the ester is $4.96 \times 10^{5}$, which is 
much larger than that of hydroxy pinonic acid $\left(K_{p}=0.2802\right)$ and of pinic acid $\left(K_{p}=0.2822\right)$.

\subsection{Volatility basis set model}

The volatility basis set model is also applied to fit the experimental SOA yields. The estimated volatility (or $c^{*}$ ) of products spans from 0.035 to $873 \mu \mathrm{g} \mathrm{m}^{-3}$. A volatility basis set of six volatility bins is chosen and the volatility bins are separated by an order-of-magnitude $\left(c^{*}: 0.01,0.1,1,10\right.$, 100 , and $1000 \mu \mathrm{g} \mathrm{m}^{-3}$ ). The mass of aerosol in bin $i$ is obtained by optimal fitting to the experimental SOA yield data. Figure 1 shows that for the volatility basis set, the predicted SOA yields agree well with the experimental SOA yield data, even at low organic mass loading $\left(<0.5 \mu \mathrm{g} \mathrm{m}^{-3}\right)$. This suggests that products with volatility as low as $c^{*}=0.01 \mu \mathrm{g} \mathrm{m}^{-3}$ (or $K_{p}=100 \mu \mathrm{g}^{-1} \mathrm{~m}^{3}$ ) are present. The quantity of aerosol in the volatility bin $i$ is in good agreement with that of the product $i$ with similar $K_{p}$ or $c^{*}$ (Table 1 ) in the $K_{p} \times 100$ case. Overall, the volatility basis set produces the smallest fitting error of SOA yield prediction over the whole range of organic mass loading (mean absolute fractional error, err $=0.1572$ ) compared to the $K_{p} \times 1$ case (err $\left.=0.1688\right)$ and the $K_{p} \times 100$ case (err $=0.1598)$.

\subsection{Temperature dependence of SOA yield}

We also investigate temperature dependence of SOA yield using the product-specific model (only the $K_{p} \times 100$ case which gives a better description of SOA yields is shown). The temperature-dependent vapor pressure of the products can be estimated using the group contribution method developed by Pankow and Asher (2008). The temperature dependence of the structural groups $(b(T))$ are assumed to follow $b(T)=B_{1} / T+B_{2}+B_{3} T+B_{4} \ln T$. The $B$ coefficients are obtained by optimal fitting to a number of compounds. In the calculation of the $K_{p}$, it is assumed that the activity coefficient is unity and the molecular weight of the product is taken as the mean molecular weight of the surrogate mixture. The $\alpha$ values determined at $293 \mathrm{~K}$ are assumed to be constant over the temperature range studied (273-313 K). The enthalpy of vaporization, $\Delta H_{v}$ of the products can also be estimated by the group contribution method. By plotting the estimated vapor pressure of the product against the temperature, the $\Delta H_{v}$ of the product can be estimated from the slope of the line following the Clausius-Clapeyron equation (see Appendix A). Estimated values of $\Delta H_{v}$ of major products are listed in Table 1.

As shown in Fig. 2, the predicted SOA yield increases as the temperature decreases, as lower temperature favors the partitioning of gas-phase reaction products into the particle phase. The model predicts a stronger temperature dependence of SOA yield than that observed by Pathak et al. (2007). The predicted SOA yields agree well with those measured at 293 and $303 \mathrm{~K}$. The mean absolute fractional
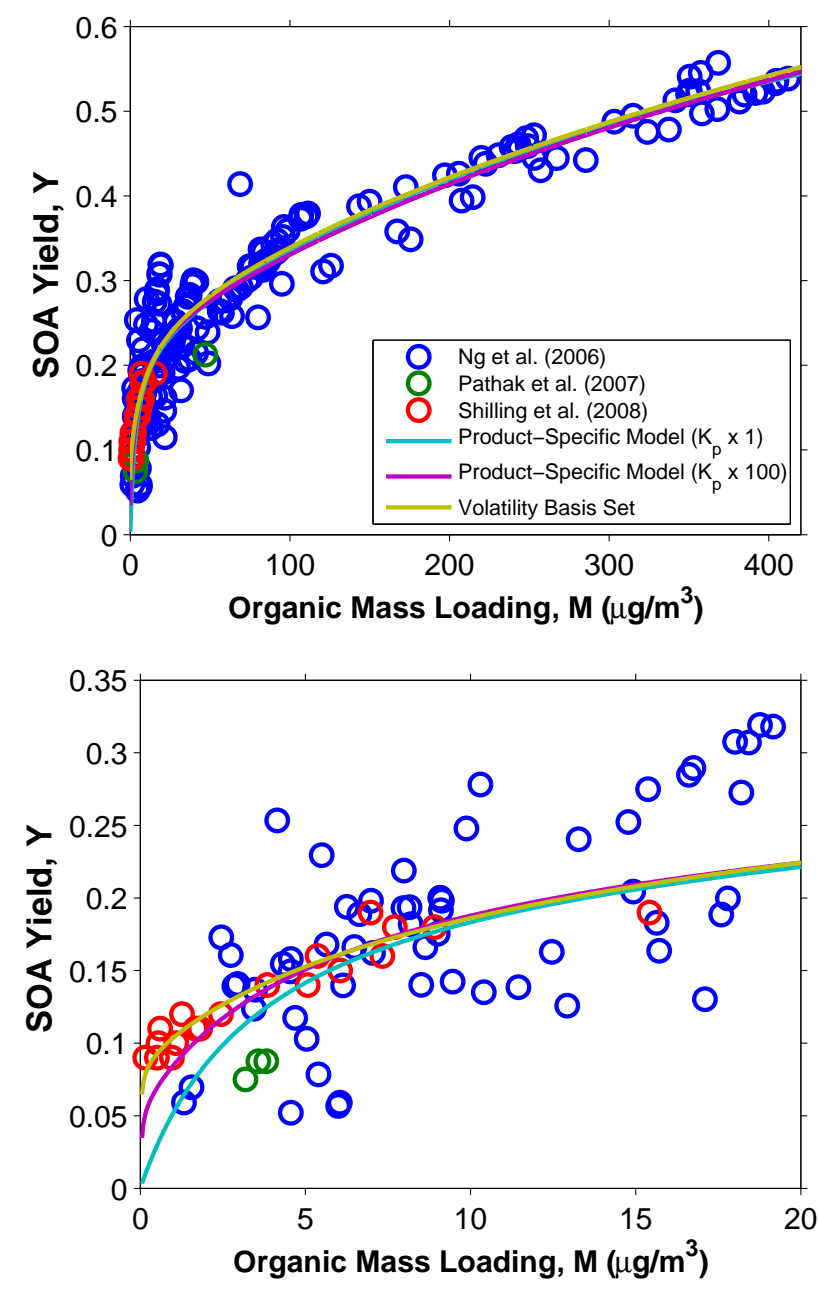

Fig. 1. SOA yield from ozonolysis of $\alpha$-pinene at different organic mass loading, $M$. Data represent experiments conducted under dry, dark, and low- $\mathrm{NO}_{\mathrm{x}}$ conditions in the presence of dry ammonium sulfate particles (Ng et al., 2006; Pathak et al., 2007; Shilling et al., 2008). Top panel: organic mass loading: $0-411 \mu \mathrm{g} \mathrm{m}^{-3}$; bottom panel: organic mass loading: $0-20 \mu \mathrm{g} \mathrm{m}^{-3}$. SOA yield data are adjusted to $293 \mathrm{~K}$, using a temperature correction factor. Lines show the model fit with the parameters given in Table 1.

error between the measured and predicted SOA yields, err, is 0.1666 and 0.0895 at 293 and $303 \mathrm{~K}$, respectively. On the other hand, the predicted SOA yields are higher than those measured at $288 \mathrm{~K}$ (err=0.6728) and $273 \mathrm{~K}$ (err=0.6266) but slightly lower than those measured at $313 \mathrm{~K}$ (err $=0.1968$ ).

In the product-specific model, the temperature dependence of the vapor pressure of major products is estimated directly using the group contribution method (Pankow and Asher, 2008). In this approach, uncertainties in the vapor pressure estimation method will lead to uncertainties in data fitting. Uncertainty in the vapor pressure estimation using the group contribution method is likely one factor contributing to a relatively large deviation between measured and predicted values at lower temperatures in the present study. 

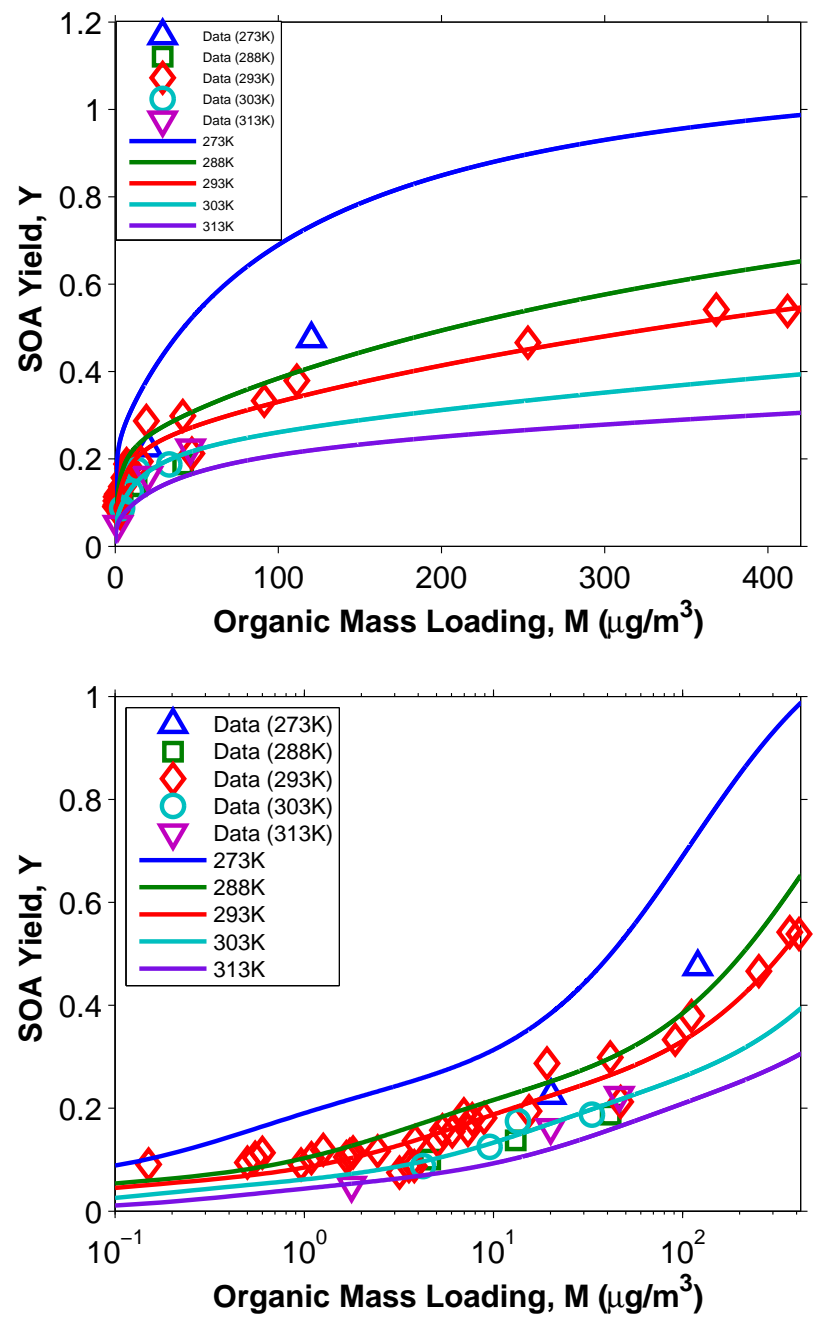

Fig. 2. Temperature dependence of SOA yield of ozonolysis of $\alpha$ pinene obtained from experiments conducted under dry, dark, and low- $\mathrm{NO}_{\mathrm{x}}$ conditions in the presence of dry ammonium sulfate particles. Data (293 K) are the final SOA yields from $\mathrm{Ng}$ et al. (2006), Pathak et al. (2007) and Shilling et al. (2008). Data from Shilling et al. (2008) have been adjusted to 293 K. Data at other temperatures are obtained from Pathak et al. (2007). The lines show the model fit at different temperatures for the $K_{p} \times 100$ case.

\section{SOA composition}

At a given temperature and organic mass loading, $M$, the mass yield of the product $i, Y_{i}$ can be determined as:

$Y_{i}=\frac{M_{i}}{\Delta H C}=\frac{M K_{p, i}}{1+M K_{p, i}} \alpha_{i}$

where the mass-based stoichiometric coefficient of the product $i, \alpha_{i}$, is obtained from the parameterization of SOA yield data using the product-specific model (Table 1$). M_{i}$ is the concentration of product $i$ in the particle phase $\left(\mu \mathrm{g} \mathrm{m}^{-3}\right)$. The SOA yield, $Y$, is the sum of the mass yields of all prod- ucts (SOA yield, $Y=\sum_{i} Y_{i}$, at a given organic mass loading. The ratio of mass yield of product $i$ to total yield $\left(Y_{i} / Y\right)$ is the relative contribution of the product $i$ to the total SOA yield (or total SOA mass).

Figure 3 shows the predicted relative contributions of the products to the SOA yield at different organic mass loading for the $K_{p} \times 100$ case. The predicted SOA composition is compared to the measured concentration of the corresponding classes of compounds in chamber experiments. Yu et al. (1999) reported the product distribution of ozonolysis of $\alpha$ pinene at $306 \mathrm{~K}$ and organic mass loading of $38.8 \mu \mathrm{g} \mathrm{m}^{-3}$ : hydroxy pinonic acid (17.7\%), pinic acid and norpinic acid (22.5\%), pinonic acid and norpinonic acid, and isomers (36.5\%), hydroxy pinonaldehyde (15.9\%), and pinonaldehyde and norpinonaldehyde (7.4\%). It is noted that organic peroxides, particle-phase reaction products (e.g., oligomers and esters), and terpenylic acid were not reported in Yu et al. (1999). Docherty et al. (2005) estimated that organic peroxides contribute $\sim 47 \%$ of the SOA mass at high organic mass loading. The concentration of terpenylic acid in chamber SOA has not been reported previously (Claeys et al., 2009). A smaller effective density of $1 \mathrm{~g} \mathrm{~cm}^{-3}$ was used to calculate the SOA mass in Yu et al. (1999). This change in density will increase the reported percentage of products. In addition, the relative abundance of products reported by Yu et al. (1999) may be overestimated if the organic peroxides, terpenylic acid, or other unidentified products contribute significantly to the SOA mass at the given organic mass loading.

As shown in the bottom panel of Fig. 3, for the $K_{p} \times 100$ case, the predicted percentage of pinonic acid is about $51 \%$, which is close to the sum of the percentages of pinonic acid and norpinonic acid and isomers and hydroxy pinonaldehyde $(52.4 \%)$. The predicted percentage of pinonaldehyde is also close to that of pinonaldehyde and norpinonaldehyde (7.4\%). On the other hand, the predicted percentage of pinic acid is about $28 \%$, which is smaller than the sum of the percentages of pinic acid and norpinic acid and hydroxy pinonic acid $(40.2 \%)$. For organic peroxides, using a hydroperoxide as surrogate gives $\sim 7 \%$ of SOA yield, which is lower than that reported by Docherty et al. (2005) at high organic mass loading. The percentage of terpenylic acid contributes about $5 \%$ of the SOA yield. Overall, the $K_{p} \times 100$ case may give a good first estimation of the gas/particle partitioning and composition of the SOA products at the given organic mass loading and temperature.

\section{$5 \mathrm{O} / \mathrm{C}$ and $\mathrm{H} / \mathrm{C}$ ratios}

The chemical composition of SOA formed from ozonolysis of $\alpha$-pinene has been recently characterized by an Aerodyne high-resolution time-of-flight aerosol mass spectrometer (HR-ToF-AMS) at $298 \mathrm{~K}$ (Shilling et al., 2009). This characterization provides measurement of the $\mathrm{O} / \mathrm{C}$ and $\mathrm{H} / \mathrm{C}$ ratios at different organic mass loadings; these data provide 
additional information about the SOA composition and impose important constraints on the SOA parameterization. As shown in Figs. 4 and 5, the data show that the O/C ratio decreases as the organic mass loading increases, while the H/C ratio increases (Shilling et al., 2009). This observation indicates, as expected, that the SOA is more oxygenated at low organic mass loading than at high organic mass loading.

$\mathrm{O} / \mathrm{C}$ and $\mathrm{H} / \mathrm{C}$ ratios of the SOA can also be determined from the predicted SOA composition. At a given organic mass loading, the number of moles of product $i, m_{i}$ can be calculated from its particle-phase mass concentration and molecular weight. The number of carbon atoms, $n_{C, i},(\mathrm{O} / \mathrm{C})_{i}$ and $(\mathrm{H} / \mathrm{C})_{i}$ ratios of the product $i$ are known (Table 1). The $\mathrm{O} / \mathrm{C}$ and $\mathrm{H} / \mathrm{C}$ ratios of the SOA can be determined as follows:

$\mathrm{O} / \mathrm{C}=\frac{\sum_{i} m_{i} \cdot n_{C, i} \cdot(\mathrm{O} / \mathrm{C})_{i}}{\sum_{i} m_{i} \cdot n_{C, i}}$

$\mathrm{H} / \mathrm{C}=\frac{\sum_{i} m_{i} \cdot n_{C, i} \cdot(\mathrm{H} / \mathrm{C})_{i}}{\sum_{i} m_{i} \cdot n_{C, i}}$

At $298 \mathrm{~K}$, for the $K_{p} \times 1$ case (Fig. 4, upper panel), the modeled $\mathrm{O} / \mathrm{C}$ ratios decrease from $\sim 0.44$ to $\sim 0.36$ as the organic mass loading increases from $0.5 \mu \mathrm{g} \mathrm{m}^{-3}$ to $150 \mu \mathrm{g} \mathrm{m}^{-3}$. The predicted $\mathrm{O} / \mathrm{C}$ ratios are higher than those in Shilling et al. (2009), except at low organic mass loading $\left(<1 \mu \mathrm{g} \mathrm{m}^{-3}\right)$. The predicted ratios decrease less rapidly as the organic mass loading increases. For the $K_{p} \times 100$ case (Fig. 4, lower panel), the predicted $\mathrm{O} / \mathrm{C}$ ratios agree quite well with those measured; predicted $\mathrm{O} / \mathrm{C}$ ratios decrease from 0.43 to 0.30 as the organic mass loading increases. On the other hand, in both $K_{p} \times 1$ and $K_{p} \times 100$ cases, the predicted $\mathrm{H} / \mathrm{C}$ ratios exceed those measured at these loadings (Fig. 5).

The $\mathrm{O} / \mathrm{C}$ ratios of selected major products range from 0.2 to 0.5 , which cover the range of the experimental $\mathrm{O} / \mathrm{C}$ ratios. On the other hand, the $\mathrm{H} / \mathrm{C}$ ratios of the selected major products range from 1.5 to 1.6 , which exceed the reported $\mathrm{H} / \mathrm{C}$ ratios (1.38-1.51). Using the experimentally identified gas-phase reaction products, the predicted $\mathrm{H} / \mathrm{C}$ ratios do not match those reported at low organic mass loading. Notably, the $\mathrm{H} / \mathrm{C}$ ratios of the major SOA products identified in the literature range from 1.5 to 1.6. In addition to uncertainties in determination of the $\mathrm{O} / \mathrm{C}$ and $\mathrm{H} / \mathrm{C}$ ratios, the formation of oligomers or organic peroxides will shift the $\mathrm{H} / \mathrm{C}$ ratio without greatly affecting the $\mathrm{O} / \mathrm{C}$ ratio (Shilling et al., 2009). Formation of esters can alter the $\mathrm{H} / \mathrm{C}$ and $\mathrm{O} / \mathrm{C}$ ratios (Müller et al., 2008). The discrepancy in the $\mathrm{H} / \mathrm{C}$ ratios based on known gas-phase products and those measured stresses the potential importance of particle-phase reactions on the determination of SOA yield and composition in the ozonolysis of $\alpha$-pinene under dry, dark, and low- $\mathrm{NO}_{\mathrm{x}}$ conditions.

Figures 4 and 5 also show the temperature dependence of the $\mathrm{O} / \mathrm{C}$ and $\mathrm{H} / \mathrm{C}$ ratios in the temperature range (273$313 \mathrm{~K}$ ). For the both $K_{p} \times 1$ and $K_{p} \times 100$ cases (Fig. 4),
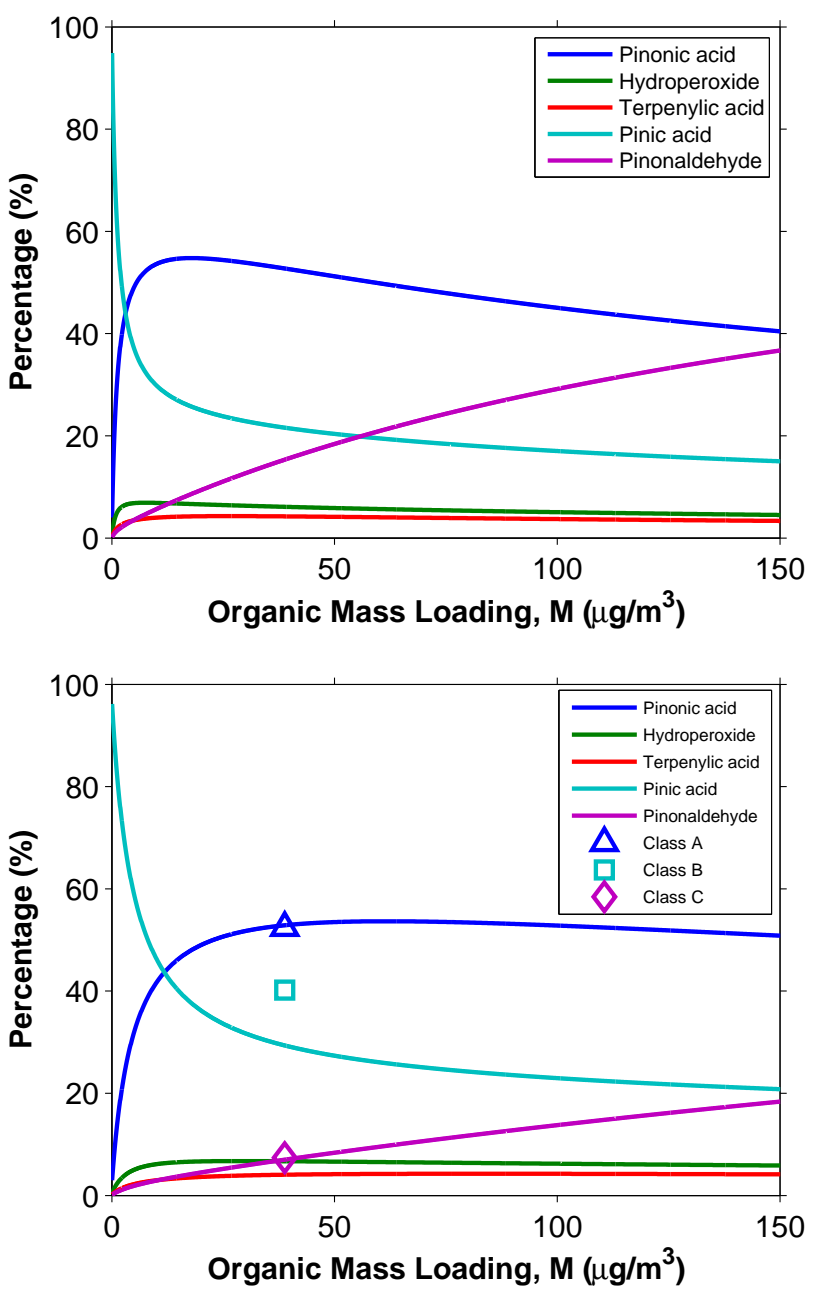

Fig. 3. Relative contributions of the modeled products to the SOA yield at different organic mass loadings for $K_{p} \times 100$ case at different temperatures (solid lines). Top panel: $293 \mathrm{~K}$; bottom panel: $306 \mathrm{~K}$; Class A data point refers to the sum of the percentages of pinonic acid, norpinonic acid and isomers, and hydroxy pinonaldehyde (Yu et al., 1999); Class B data point refers to the sum of the percetages of pinic acid, norpinic acid, and hydroxy pinonic acid (Yu et al., 1999); Class C data point refers to the sum of the percentages of pinonaldehyde and norpinonaldehyde (Yu et al., 1999).

the modeled $\mathrm{O} / \mathrm{C}$ ratio increases when the temperature increases. On the other hand, the modeled $\mathrm{H} / \mathrm{C}$ ratio decreases when the temperature increases (Fig. 5). At a higher temperature, the less volatile gas-phase products which are usually more oxygenated (i.e., usually a higher $\mathrm{O} / \mathrm{C}$ ratio and a lower $\mathrm{H} / \mathrm{C}$ ratio) partition preferentially into the particle phase. As shown in Fig. 3 ( $K_{p} \times 100$ case), the contribution of pinic acid, which is the least volatile product and is more oxygenated, increases when the temperature increases from 293 to $306 \mathrm{~K}$. On the other hand, the relative abundance of pinonaldehyde, which is the most volatile product and is the least oxygenated, decreases with increasing temperature. 

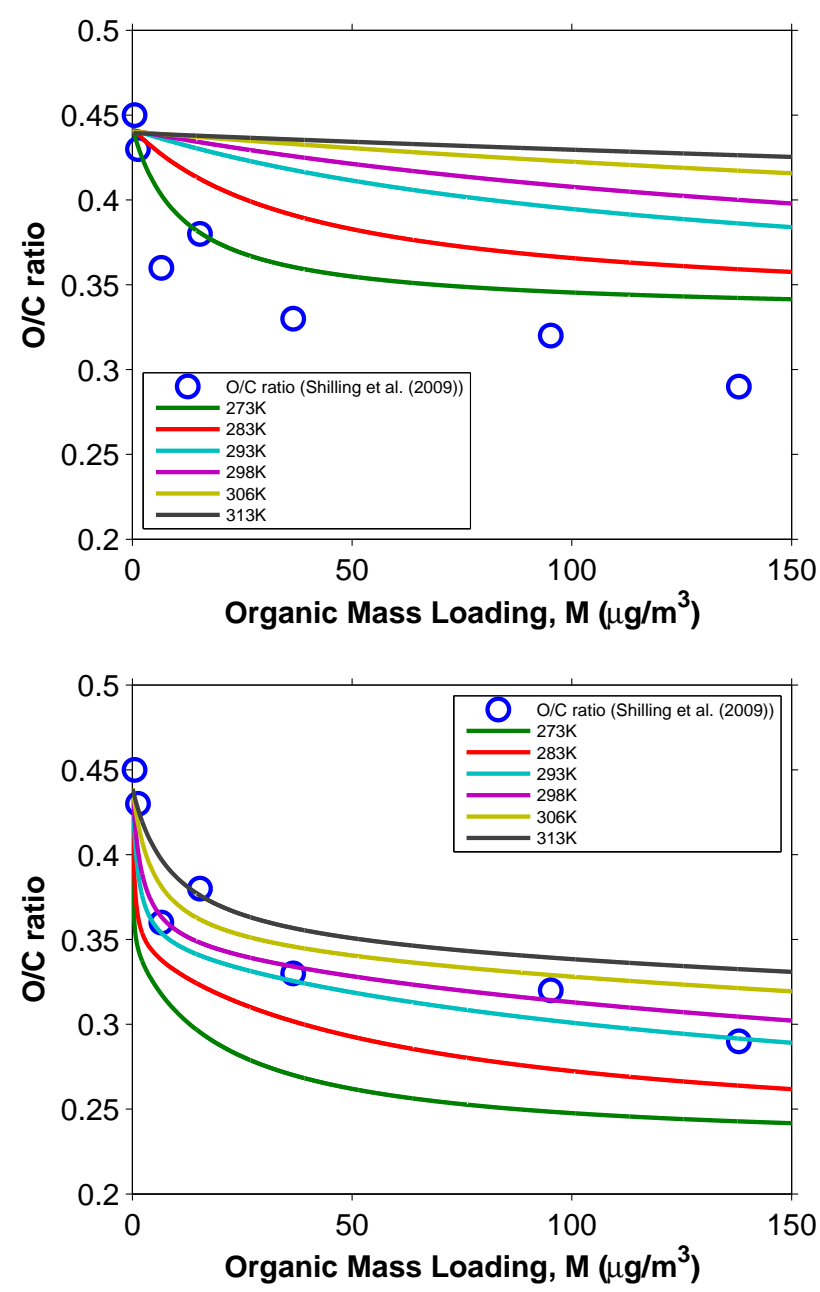

Fig. 4. O/C ratio of SOA formed from the ozonolysis of $\alpha$-pinene under dry, dark, and low- $\mathrm{NO}_{\mathrm{x}}$ conditions in the presence of dry ammonium sulfate particles as a function of organic mass loading, $M$, at different temperatures. Top panel: $K_{p} \times 1$ case; bottom panel: $K_{p} \times 100$ case; Blue open circles represent measured O/C ratios reported by Shilling et al. (2009) at $298 \mathrm{~K}$.

The effect of particle-phase reactions on $\mathrm{O} / \mathrm{C}$ and $\mathrm{H} / \mathrm{C}$ ratios at different temperatures is not considered.

We also report here on an $\alpha$-pinene ozonolysis experiment conducted in the Caltech laboratory chamber under dry, dark, and low- $\mathrm{NO}_{\mathrm{x}}$ conditions in the presence of dry $\left(\mathrm{NH}_{4}\right)_{2} \mathrm{SO}_{4}$ particles to generate a data set comparable to that of Shilling et al. $(2008,2009)$. The chemical composition of the SOA was continuously monitored using an Aerodyne HR-ToFAMS. Details of the experiment are given in Appendix B. Figure 6 shows the time evolution of $\alpha$-pinene concentration, organic mass loading, and aerosol $\mathrm{O} / \mathrm{C}$ and $\mathrm{H} / \mathrm{C}$ ratios. Once the ozone is injected, $\alpha$-pinene oxidation commences, and the organic mass loading increases almost immediately. When $\alpha$-pinene is completely reacted, organic aerosol mass loading remains unchanged. These observations are consistent with those reported by $\mathrm{Ng}$ et al. (2006).
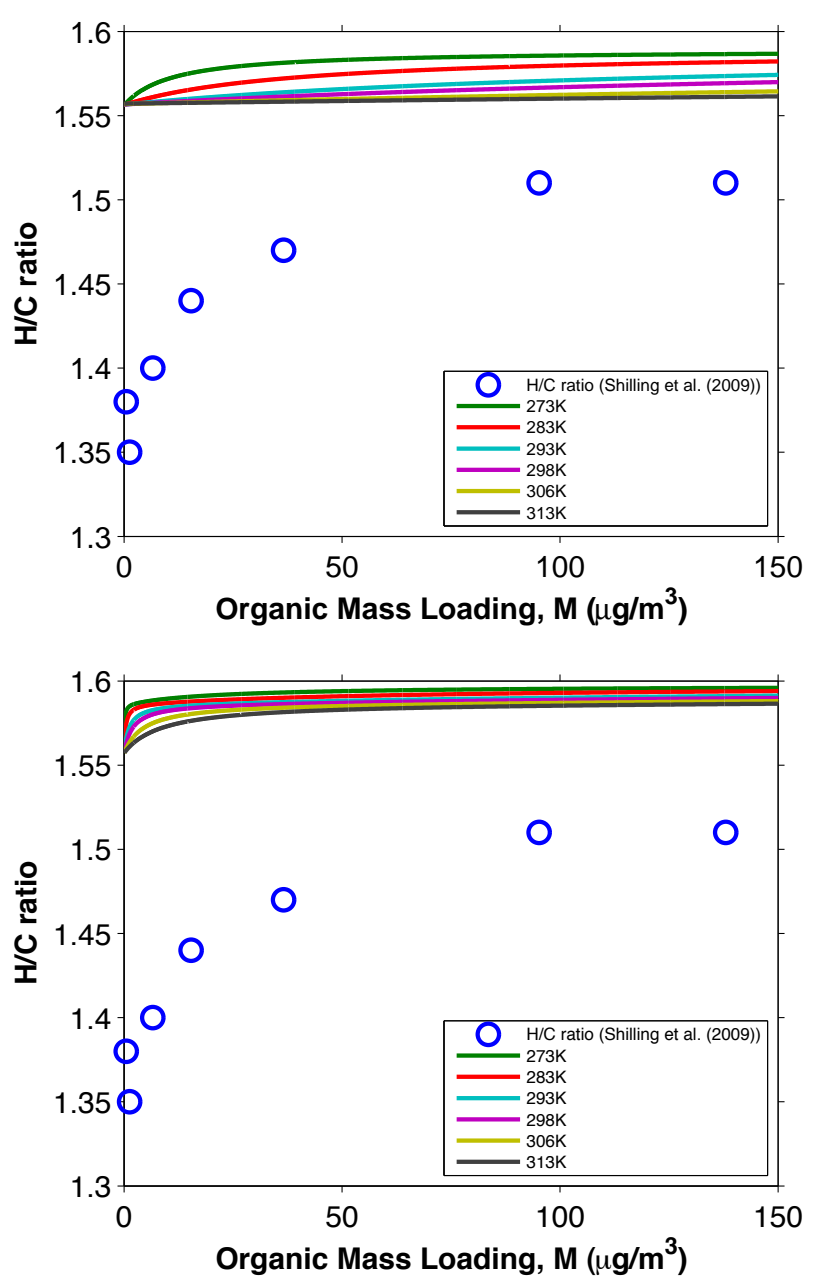

Fig. 5. H/C ratio of SOA formed from the ozonolysis of $\alpha$-pinene under dry, dark, and low- $\mathrm{NO}_{\mathrm{x}}$ conditions in the presence of dry ammonium sulfate particles as a function of organic mass loading, $M$, at different temperatures. Top panel: $K_{p} \times 1$ case; bottom panel: $K_{p} \times 100$ case; Blue open circles represent measured H/C ratios reported by Shilling et al. (2009) at $298 \mathrm{~K}$.

Measured $\mathrm{O} / \mathrm{C}$ and $\mathrm{H} / \mathrm{C}$ ratios as a function of organic mass loading are shown in Fig. 7. The data scatter reflects the inherent uncertainty in measurement of $\mathrm{O} / \mathrm{C}$ and $\mathrm{H} / \mathrm{C}$ ratios at low organic mass loading. Generally, the $\mathrm{H} / \mathrm{C}$ ratio increases as time increases, while the $\mathrm{O} / \mathrm{C}$ ratio decreases. The trends in $\mathrm{O} / \mathrm{C}$ and $\mathrm{H} / \mathrm{C}$ ratios are in good agreement with those reported by Shilling et al. (2009). The absolute values of the $\mathrm{O} / \mathrm{C}$ ratios are slightly lower than those reported by Shilling et al. (2009), but well within the experimental uncertainty. When all $\alpha$-pinene is consumed and the SOA growth has leveled out $\left(\sim 58 \mu \mathrm{g} \mathrm{m}^{-3}\right), \mathrm{O} / \mathrm{C}$ and $\mathrm{H} / \mathrm{C}$ ratios and fragment mass spectrum (not shown here) remain unchanged. As discussed by $\mathrm{Ng}$ et al. (2006), the first oxidation step in the ozonolysis of $\alpha$-pinene (a hydrocarbon with a single double bond) is most likely the rate-determining step in SOA formation. Either the condensable products are the initial reaction 


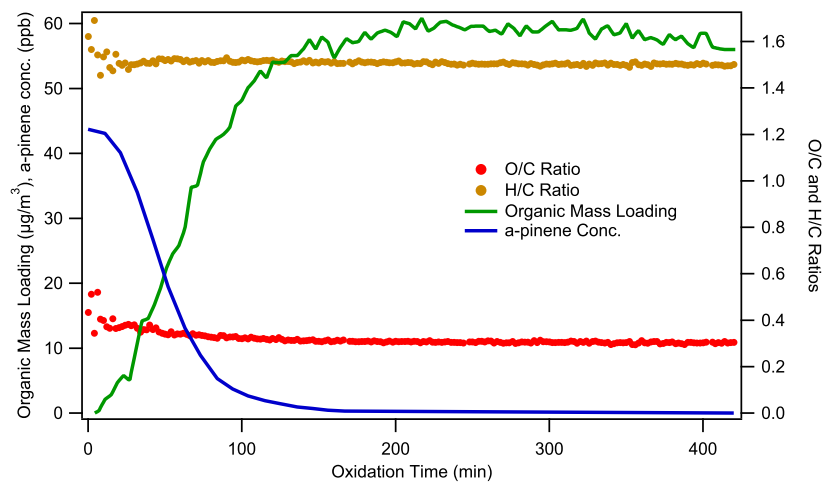

Fig. 6. Time evolution of $\alpha$-pinene concentration, organic mass loading, and $\mathrm{O} / \mathrm{C}$ and $\mathrm{H} / \mathrm{C}$ ratios during ozonolysis of $\alpha$-pinene under dry, dark, and low- $\mathrm{NO}_{\mathrm{x}}$ conditions in the presence of dry ammonium sulfate particles. Experiment conducted in the Caltech laboratory chamber. Conditions given in Appendix B.

products of the parent hydrocarbon oxidation (first-or higher generation products), or subsequent reactions (in either the gas or particle phase) proceed at relatively fast rates. Thus, the instantaneous product spectrum can be considered as that at equilibrium during the chamber phase.

To determine the extent to which an equilibrium state is achieved, the chemical composition of SOA can be measured by the Aerodyne HR-ToF-AMS over the course of the chamber experiments. The change in element-to-carbon ratios (e.g., $\mathrm{O} / \mathrm{C}, \mathrm{H} / \mathrm{C}$ ratios) can provide insight about the change in SOA composition. If the ratios or the mass spectra do not vary with time, this may suggest that an equilibrium state is achieved within the timescale of the chamber experiment. In that case, major experimentally identified products (both particle-phase and gas-phase reaction products) can be chosen as SOA surrogates in the product-specific model. In addition, the $\mathrm{O} / \mathrm{C}, \mathrm{H} / \mathrm{C}, \mathrm{N} / \mathrm{C}$, or $\mathrm{S} / \mathrm{C}$ ratios can be calculated from the detailed gas-chemistry model coupled with gas/particle partitioning theory.

Recently, Dzepina et al. (2009) suggest that the O/C ratio and volatility can be used to compare modeled and measured SOA. The authors calculate $\mathrm{O} / \mathrm{C}$ ratios using various models and compare these to the measured $\mathrm{O} / \mathrm{C}$ ratios of ambient Mexico City aerosol. They find that $\mathrm{O} / \mathrm{C}$ ratios predicted by different models do not agree and are generally lower than the measured ratios.

In the present study, we show that although good agreement in $\mathrm{O} / \mathrm{C}$ ratio between observations and predictions can exist, a discrepancy in $\mathrm{H} / \mathrm{C}$ ratio is not removed by data fitting. Hence, in addition to the $\mathrm{O} / \mathrm{C}$ ratio, other element-tocarbon ratios such as $\mathrm{H} / \mathrm{C}$ are important for modeling fitting and comparison. S/C and N/C ratios could be used once accurate determinations can be made using the AMS. These element-to-carbon ratios can also be calculated using detailed gas-chemistry models coupled with gas/particle par-

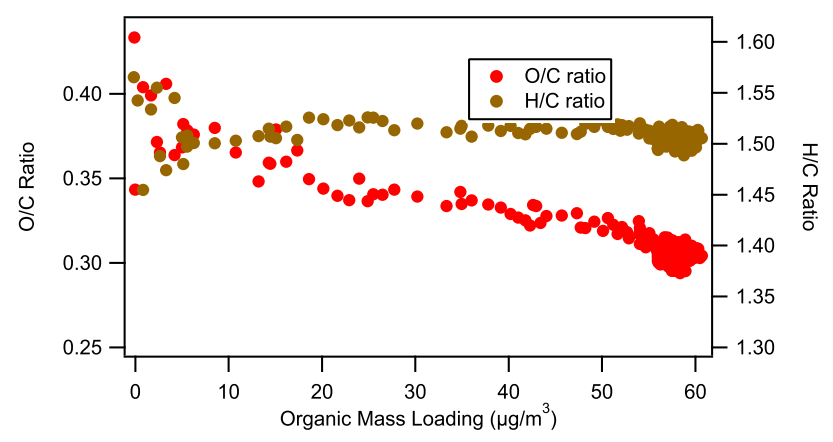

Fig. 7. $\mathrm{O} / \mathrm{C}$ and $\mathrm{H} / \mathrm{C}$ ratios of SOA formed from the ozonolysis of $\alpha$-pinene under dry, dark, and low- $\mathrm{NO}_{\mathrm{x}}$ conditions in the presence of dry ammonium sulfate particles as function of organic mass loading, $M$. Experiment conducted in the Caltech laboratory chamber. Conditions given in Appendix B.

titioning theory and can be used as additional constraints on the SOA parameterization in chamber experiments and modeling studies.

\section{Discussion}

SOA yields from volatile organic compounds are determined from laboratory chamber data. Gas-particle partitioning of semivolatile oxidation products forms the basis of all current models of SOA formation. As identification of aerosolphase products has become feasible using advanced mass spectrometric techniques, we investigate the extent to which a product-specific model, certain parameters of which are determined from chamber data, can be used to represent SOA formation. In the present work we address this question using data on SOA formation in the $\alpha$-pinene/ozone system. While the product specific model can be fitted to available chamber data, fitting of the product-specific model required increasing estimated equilibrium partitioning coefficients by two orders of magnitude, and the predicted fractional contributions of the selected products to SOA are unreasonable in several respects and no better than a fitting of the data to a volatility basis set representation.

The performance of the product-specific model is most likely hindered by lack of explicit inclusion of particle-phase accretion compounds that are almost certainly present but have yet to be identified in this system. Prospects for identification of the majority of SOA products for major VOC classes remain promising. However, for the near future, empirical product Odum-type or volatility basis set models remain the approaches of choice. 


\section{Appendix A}

\section{The gas-particle partitioning coefficient}

The gas-particle partitioning coefficient for compound $i$ to a condensed phase of $i$ only is given by (Pankow, 1994a,b)

$$
K_{p, i}=\frac{R T}{10^{6} M W_{i} p_{L, i}^{o}}
$$

where $R=8.2 \times 10^{-5} \mathrm{~m}^{3}$ atm mol ${ }^{-1} \mathrm{~K}^{-1}, \quad M W_{i}=$ molecular weight of $i\left(\mathrm{~g} \mathrm{~mol}^{-1}\right)$ and $p_{L, i}^{o}$ is the vapor pressure of pure $i$ as a liquid (atm). When multiple condensed-phase compounds exists

$$
K_{p, i}=\frac{R T f}{10^{6} \overline{M W} \zeta_{i} p_{L, i}^{o}}
$$

where $f=$ weight fraction of the total particulate matter that is the absorbing phase, $\overline{M W}$ is the mean molecular weight of the absorbing organic phase $\left(\mathrm{g} \mathrm{mol}^{-1}\right)$, and $\zeta_{i}=$ mole-fraction based activity coefficient. $K_{p, i}$ varies as a function of $T$, through both its explicit dependence on $T$ as well as the strong dependence of $p_{L, i}^{o}$ on $T$. The value of $K_{p, i}$ is also influenced by $\zeta_{i}$ and $\overline{M W}$ owing to the types and amounts of condensed-phase compounds.

The vapor pressure of each component obeys the ClausiusClapeyron equation,

$$
p_{L, i}^{o}(T)=p_{L, i}^{o}\left(T_{o}\right) \exp \left[-\frac{\Delta H_{v, i}}{R}\left(\frac{1}{T}-\frac{1}{T_{o}}\right)\right]
$$

For a set of compounds at a given $T, p_{L, i}^{o}$ tends to decrease with increasing $\Delta H_{v, i}$.

The variation of gas-partitioning coefficient with temperature results from variation of $p_{L, i}^{o}$ as well as the explicit dependence on $T$,

$$
\begin{aligned}
\frac{K_{p, i}(T)}{K_{p, i}\left(T_{o}\right)} & =\left(\frac{T}{T_{o}}\right) \frac{p_{L, i}^{o}\left(T_{o}\right)}{p_{L, i}^{o}(T)} \\
& =\left(\frac{T}{T_{o}}\right) \exp \left[-\frac{\Delta H_{v, i}}{R}\left(\frac{1}{T}-\frac{1}{T_{o}}\right)\right]
\end{aligned}
$$

Following Pankow and Chang (2008), one may choose $\Delta H_{v}=100 \mathrm{~kJ} \mathrm{~mol}^{-1}$ as a "reference" $\Delta H_{v, i}$ value, so that any $\Delta H_{v, i}$ can be written as a multiple of the reference value, $\Delta H_{v, i}=a_{i} \times 100 \mathrm{~kJ} \mathrm{~mol}^{-1}$. For $T_{o}=293 \mathrm{~K}$, for $a=1$, a $10 \mathrm{~K}$ decrease in $T$ leads to

$$
\begin{aligned}
\frac{K_{p, i}(283)}{K_{p, i}(293)} & =\left(\frac{283}{293}\right) \exp \left[-\frac{100}{R}\left(\frac{1}{283}-\frac{1}{293}\right)\right] \\
& =4.1
\end{aligned}
$$

Thus, for a compound with $\Delta H_{v}=100 \mathrm{~kJ} \mathrm{~mol}^{-1}$, a $10 \mathrm{~K}$ decrease in temperature leads to a factor of 4 increase in $K_{p, i}$. For a compound with $a_{i}=0.5$, the increase of $K_{p, i}$ for a $10 \mathrm{~K}$ decrease in $T$ is $\sim$ a factor of 2 . Note that the factor $\left(T / T_{o}\right)$ exerts only a minor effect compared to that from the temperature dependence of $p_{L, i}^{o}$.

\section{Appendix B}

\section{Measurement of $\mathrm{O} / \mathrm{C}$ and $\mathrm{H} / \mathrm{C}$ ratios of SOA from $\alpha$-pinene ozonolysis}

To provide an additional set of data on the $\mathrm{O} / \mathrm{C}$ ratio of SOA generated from $\alpha$-pinene ozonolysis, an experiment was performed in one of the dual Caltech $28-\mathrm{m}^{3}$ Teflon chambers. Details of the facility have been described elsewhere (Cocker et al., 2001; Keywood et al., 2004). Before the experiment, the chamber was flushed continuously with dry, purified air for at least $24 \mathrm{~h}$. Aerosol number concentration, size distribution, and volume concentrations were measured by a differential mobility analyzer (DMA, TSI model 3081) coupled with a condensation nucleus counter (TSI model 3760). Ammonium sulfate seed particles were generated by atomizing an aqueous solution of $0.015 \mathrm{M}\left(\mathrm{NH}_{4}\right)_{2} \mathrm{SO}_{4}$ with a constantrate atomizer. The volume concentration of the seed particles was $12 \mu \mathrm{m}^{3} \mathrm{~cm}^{-3}$.

The parent hydrocarbon, $\alpha$-pinene, and an $\mathrm{OH}$ scavenger, cyclohexane, were then introduced separately by injecting known volumes of the liquid hydrocarbon into a glass bulb, subsequently carried into the chamber by an air stream at $5 \mathrm{~L} \mathrm{~min}^{-1}$. The mixing ratio of $\alpha$-pinene was monitored with a gas chromatograph coupled with a flame ionization detector (GC-FID, Agilent model 6890N). The initial mixing ratio of $\alpha$-pinene was $44 \mathrm{ppb}$. The estimated mixing ratio of cyclohexane was $37 \mathrm{ppm}$, which corresponds to a rate of cyclohexane $+\mathrm{OH} 100$ times faster than that of $\alpha$-pinene $+\mathrm{OH}$.

Ozone was generated with a UV lamp ozone generator (EnMet Corporation, MI), and monitored with a commercial ozone analyzer (Horiba Instruments, CA). Ozone injection was stopped after the ozone concentration reached $180 \mathrm{ppb}$. The aerosol growth data were corrected for wall deposition of particles. First-order size dependent wall loss coefficents were determined from a separate seed-only experiment. The final SOA volume was $46 \mu \mathrm{m}^{3} \mathrm{~cm}^{-3}$, as measured by the DMA.

Real-time particle mass spectra were collected continuously by an Aerodyne High Resolution Time-of-Flight Aerosol Mass Spectrometer (HR-ToF-AMS). The HR-ToFAMS is described in detail elsewhere (Canagaratna et al. (2007) and references therein). The HR-ToF-AMS switched once every minute between the high resolution "W-mode" and the lower resolution, higher sensitivity "V-mode". The "V-mode" data were analyzed using a fragmentation table to separate sulfate, ammonium, and organic spectra and to time-trace specific mass-to-charge ratios. "W-mode" data were analyzed using a separate high-resolution spectra toolbox known as PIKA to determine the chemical formulas contributing to distinct mass-to-charge ratios (DeCarlo et al., 2006).

To determine elemental ratios, the computational toolbox Analytical Procedure for Elemental Separation (APES) was used. This toolbox applies the analysis procedure described 
in Aiken et al. (2007) to the high-resolution "W-mode" data. The particle-phase signal of $\mathrm{CO}^{+}$and the organic contribution to $\mathrm{H}_{\mathrm{x}} \mathrm{O}^{+}$ions were estimated as described in Aiken et al. (2008). It is noted that chamber air is cleaned through a series of chemical denuders and filters. Fourier transform infrared spectroscopy measurements show that the concentrations of $\mathrm{CO}_{2}$ in the chamber air is nominally the same as that in the atmosphere. Due to the relatively large SOA loadings generated in this study, the sensitivity of the $\mathrm{O} / \mathrm{C}$ calculation to the $\mathrm{CO}_{2}$ concentration input is relatively small.

Acknowledgements. This work was supported by the Office of Science (BER), U.S. Department of Energy, Grant No. DE-FG0205ER63983 and the U.S. Environmental Protection Agency under STAR Agreement RD-833749. It has not been formally reviewed by the EPA. The views expressed in this document are solely those of the authors and the EPA does not endorse any products or commerical services mentioned in this publication.

Edited by: A. Nenes

\section{References}

Aiken, A. C., DeCarlo, P. F., and Jimenez, J. L.: Elemental analysis of organic species with electron ionization high-resolution mass spectrometry, Anal. Chem., 79, 8350-8358, 2007.

Aiken, A. C., Decarlo, P. F., Kroll, J. H., Worsnop, D. R., Huffman, J. A., Docherty, K. S., Ulbrich, I. M., Mohr, C., Kimmel, J. R., Sueper, D., Sun, Y., Zhang, Q., Trimborn, A., Northway, M., Ziemann, P. J., Canagaratna, M. R., Onasch, T. B., Alfarra, M. R., Prevot, A. S. H., Dommen, J., Duplissy, J., Metzger, A., Baltensperger, U., and Jimenez, J. L.: O/C and OM/OC ratios of primary, secondary, and ambient organic aerosols with high-resolution time-of-flight aerosol mass spectrometry, Environ. Sci. Technol., 42, 4478-4485, 2008.

Bahreini, R., Keywood, M. D., Ng, N. L., Varutbangkul, V., Gao, S., Flagan, R. C., Seinfeld, J. H., Worsnop, D. R., and Jimenez, J. L.: Measurements of secondary organic aerosol from oxidation of cycloalkenes, terpenes, and m-xylene using an Aerodyne aerosol mass spectrometer, Environ. Sci. Technol., 39, 5674-5688, 2005.

Bilde, M. and Pandis, S. N.: Evaporation rates and vapor pressures of individual aerosol species formed in the atmospheric oxidation of alpha- and beta-pinene, Environ. Sci. Technol., 35, 33443349, 2001.

Canagaratna, M. R., Jayne, J. T., Jimenez, J. L., Allan, J. D., Alfarra, M. R., Zhang, Q., Onasch, T. B., Drewnick, F., Coe, H., Middlebrook, A., Delia, A., Williams, L. R., Trimborn, A. M., Northway, M. J., DeCarlo, P. F., Kolb, C. E., Davidovits, P., and Worsnop, D. R.: Chemical and microphysical characterization of ambient aerosols with the aerodyne aerosol mass spectrometer, Mass. Spectrom. Rev., 26, 185-222, 2007.

Chan, A. W. H., Kroll, J. H., Ng, N. L., and Seinfeld, J. H.: Kinetic modeling of secondary organic aerosol formation: effects of particle- and gas-phase reactions of semivolatile products, Atmos. Chem. Phys., 7, 4135-4147, 2007, http://www. atmos-chem-phys.net/7/4135/2007/.
Chen, J. J. and Griffin, R. J.: Modeling secondary organic aerosol formation from oxidation of alpha-pinene, beta-pinene, and dlimonene, Atmos. Environ., 39, 7731-7744, 2005.

Claeys, M., Iinuma, Y., Szmigielski, R., Surratt, J. D., Blockhuys, F., Van Alsenoy, C., Böge, O., Sierau, B., Gómez-González, Y., Vermeylen, R., Van der Veken, P., Shahgholi, M., Chan, A. W. H., Herrmann, H., Seinfeld, J. H., and Maenhaut, W.: Terpenylic acid and related compounds from the oxidation of $\alpha$-pinene: Implications for new particle formation and growth above forests, Environ. Sci. Technol., in press, 2009.

Cocker, D. R., Flagan, R. C., and Seinfeld, J. H.: State-of-the-art chamber facility for studying atmospheric aerosol chemistry, Environ. Sci. Technol., 35, 2594-2601, 2001.

DeCarlo, P. F., Kimmel, J. R., Trimborn, A., Northway, M. J., Jayne, J. T., Aiken, A. C., Gonin, M., Fuhrer, K., Horvath, T., Docherty, K. S., Worsnop, D. R., and Jimenez, J. L.: Field-deployable, high-resolution, time-of-flight aerosol mass spectrometer, Anal. Chem., 78, 8281-8289, 2006.

Docherty, K. S., Wu, W., Lim, Y. B., and Ziemann, P. J.: Contributions of organic peroxides to secondary aerosol formed from reactions of monoterpenes with O-3, Environ. Sci. Technol., 39, 4049-4059, 2005.

Donahue, N. M., Robinson, A. L., Stanier, C. O., and Pandis, S. N.: Coupled partitioning, dilution, and chemical aging of semivolatile organics, Environ. Sci. Technol., 40, 2635-2643, 2006.

Dzepina, K., Volkamer, R. M., Madronich, S., Tulet, P., Ulbrich, I. M., Zhang, Q., Cappa, C. D., Ziemann, P. J., and Jimenez, J. L.: Evaluation of new secondary organic aerosol models for a case study in Mexico City, Atmos. Chem. Phys. Discuss., 9, 4417-4488, 2009, http://www.atmos-chem-phys-discuss.net/9/ $4417 / 2009 /$.

Gao, S., Keywood, M., Ng, N. L., Surratt, J., Varutbangkul, V., Bahreini, R., Flagan, R. C., and Seinfeld, J. H.: Low-molecularweight and oligomeric components in secondary organic aerosol from the ozonolysis of cycloalkenes and alpha-pinene, J. Phys. Chem. A, 108, 10147-10164, 2004.

Hallquist, M., Wenger, J. C., Baltensperger, U., Rudich, Y., Simpson, D., Claeys, M., Dommen, J., Donahue, N. M., George, C., Goldstein, A. H., Hamilton, J. F., Herrmann, H., Hoffmann, T., Iinuma, Y., Jang, M., Jenkin, M. E., Jimenez, J. L., Kiendler-Scharr, A., Maenhaut, W., McFiggans, G., Mentel, Th. F., Monod, A., Prévôt, A. S. H., Seinfeld, J. H., Surratt, J. D., Szmigielski, R., and Wildt, J.: The formation, properties and impact of secondary organic aerosol: current and emerging issues, Atmos. Chem. Phys., 9, 5155-5235, 2009, http://www. atmos-chem-phys.net/9/5155/2009/.

Iinuma, Y., Boge, O., Gnauk, T., and Herrmann, H.: Aerosolchamber study of the alpha-pinene/O-3 reaction: influence of particle acidity on aerosol yields and products, Atmos. Environ., 38, 761-773, 2004.

Jenkin, M. E.: Modelling the formation and composition of secondary organic aerosol from $\alpha$ - and $\beta$-pinene ozonolysis using MCM v3, Atmos. Chem. Phys., 4, 1741-1757, 2004, http: //www.atmos-chem-phys.net/4/1741/2004/.

Keywood, M. D., Varutbangkul, V., Bahreini, R., Flagan, R. C., and Seinfeld, J. H.: Secondary organic aerosol formation from the ozonolysis of cycloalkenes and related compounds, Environ. Sci. Technol., 38, 4157-4164, 2004. 
Kroll, J. H. and Seinfeld, J. H.: Representation of secondary organic aerosol laboratory chamber data for the interpretation of mechanisms of particle growth, Environ. Sci. Technol., 39, 4159-4165, 2005.

Müller, L., Reinnig, M.-C., Warnke, J., and Hoffmann, Th.: Unambiguous identification of esters as oligomers in secondary organic aerosol formed from cyclohexene and cyclohexene/apinene ozonolysis, Atmos. Chem. Phys., 8, 1423-1433, 2008, http://www.atmos-chem-phys.net/8/1423/2008/.

Ng, N. L., Kroll, J. H., Keywood, M. D., Bahreini, R., Varutbangkul, V., Flagan, R. C., Seinfeld, J. H., Lee, A., and Goldstein, A. H.: Contribution of first- versus second-generation products to secondary organic aerosols formed in the oxidation of biogenic hydrocarbons, Environ. Sci. Technol., 40, 2283-2297, 2006.

Odum, J. R., Hoffmann, T., Bowman, F., Collins, D., Flagan, R. C., and Seinfeld, J. H.: Gas/particle partitioning and secondary organic aerosol yields, Environ. Sci. Technol., 30, 2580-2585, 1996.

Pankow, J. F.: An absorption-model of gas-particle partitioning of organic-compounds in the atmosphere, Atmos. Environ., 28, 185-188, 1994a.

Pankow, J. F.: An absorption-model of the gas aerosol partitioning involved in the formation of secondary organic aerosol, Atmos. Environ., 28, 189-193, 1994b.

Pankow, J. F. and Asher, W. E.: SIMPOL.1: a simple group contribution method for predicting vapor pressures and enthalpies of vaporization of multifunctional organic compounds, Atmos. Chem. Phys., 8, 2773-2796, 2008, http://www. atmos-chem-phys.net/8/2773/2008/.

Pankow, J. F. and Chang, E. I.: Variation in the sensitivity of predicted levels of atmospheric organic particulate matter (OPM), Environ. Sci. Technol., 42, 7321-7329, 2008.

Pankow, J. F., Seinfeld, J. H., Asher, W. E., and Erdakos, G. B.: Modeling the formation of secondary organic aerosol. 1. Application of theoretical principles to measurements obtained in the alpha-pinene/, beta- pinene/, sabinene/, Delta(3)-carene/, and cyclohexene/ozone systems, Environ. Sci. Technol., 35, 11641172, 2001.
Pathak, R. K., Stanier, C. O., Donahue, N. M., and Pandis, S. N.: Ozonolysis of alpha-pinene at atmospherically relevant concentrations: Temperature dependence of aerosol mass fractions (yields), J. Geophys. Res.-Atmos., 112, D03201, doi:10.1029/2006JD007436, 2007.

Presto, A. A. and Donahue, N. M.: Investigation of alpha-pinene plus ozone secondary organic aerosol formation at low total aerosol mass, Environ. Sci. Technol., 40, 3536-3543, 2006.

Seinfeld, J. H., Erdakos, G. B., Asher, W. E., and Pankow, J. F.: Modeling the formation of secondary organic aerosol (SOA). 2. The predicted effects of relative humidity on aerosol formation in the alpha-pinene-, beta-pinene-, sabinene-, Delta(3)-Carene, and cyclohexene-ozone systems, Environ. Sci. Technol., 35, 1806-1817, 2001.

Shilling, J. E., Chen, Q., King, S. M., Rosenoern, T., Kroll, J. H., Worsnop, D. R., McKinney, K. A., and Martin, S. T.: Particle mass yield in secondary organic aerosol formed by the dark ozonolysis of a-pinene, Atmos. Chem. Phys., 8, 2073-2088, 2008, http://www.atmos-chem-phys.net/8/2073/2008/.

Shilling, J. E., Chen, Q., King, S. M., Rosenoern, T., Kroll, J. H., Worsnop, D. R., DeCarlo, P. F., Aiken, A. C., Sueper, D., Jimenez, J. L., and Martin, S. T.: Loading-dependent elemental composition of $\alpha$-pinene SOA particles, Atmos. Chem. Phys., 9, 771-782, 2009, http://www.atmos-chem-phys.net/9/771/2009/.

Stanier, C. O., Donahue, N., and Pandis, S. N.: Parameterization of secondary organic aerosol mass fractions from smog chamber data, Atmos. Environ., 42, 2276-2299, 2008.

Yu, J. Z., Cocker, D. R., Griffin, R. J., Flagan, R. C., and Seinfeld, J. H.: Gas-phase ozone oxidation of monoterpenes: Gaseous and particulate products, J. Atmos. Chem., 34, 207-258, 1999. 